\title{
Fazer religião em público: encenações religiosas e influência pública
}

\section{Making religion in public: religious staging and public influence}

Paula Montero*

* Universidade de São Paulo - São Paulo, SP, Brasil pmontero@usp.br

Aramis Luis Silva*

** Universidade Federal de São Paulo - Santos, SP, Brasil Professor visitante aramisluis@uol.com.br

\section{Lilian Sales ${ }^{\star \star \star}$}

*** Universidade Federal de São Paulo - Guarulhos, SP, Brasil lilian.sales@unifesp.br 


\title{
Resumo
}

Levando em conta a expansão do ativismo de diversas agências religiosas nas mais variadas arenas públicas nacionais, este artigo visa trabalhar o problema da reconfiguração recente do secularismo brasileiro. A partir da análise de três casos concretos - cerimônia de inauguração do Tempo de Salomão, repercussão midiática de uma pastora transgênera e controvérsias no Supremo Tribunal Federal envolvendo agentes religiosos -, procuraremos demonstrar como as diversas dinâmicas de produção de visibilidade observadas resultam em um novo entendimento do que é "fazer religião" em público e, no limite, modificam a configuração de nossa ordem jurídica secular. Seguindo por esse caminho e observando o modo como a publicização da experiência sacraliza (moraliza) problemas privados tornando-os públicos, constata-se que grande parte da eficácia da linguagem religiosa contemporânea está menos na imposição de uma mensagem do que na qualidade e plasticidade de suas encenações nas diferentes arenas.

Palavras-chave: religião, secularismo, publicização; arenas públicas.

\begin{abstract}
This article analyses the problem of the recent reconfiguration of Brazilian secularism, taking into account the expansion of the activism of several religious agencies in the most varied national public arenas. We observed three empirical cases involving religious agents - the Solomon's Temple Inauguration ceremony, the media's repercussion of a transgender pastor and two controversies in the Federal Supreme Court - analyzing the different dynamics of production of visibility that results in a new understanding of what it is to "do religion" in public. In this sense, it was observed how to make the experience public sacralizes (moralises) the private problems and it has been found that the effectiveness of contemporary religious language cames much more from the quality and plasticity of its scenarios in the different arenas than of the imposition of a religion's message.
\end{abstract}

Keywords: religion, secularism, publicity; public arenas. 


\section{Introdução ${ }^{1}$}

Este artigo visa trabalhar o problema da reconfiguração recente do secularismo brasileiro, historicamente demarcado pela oposição entre a Igreja Católica e o Estado, tendo em vista a expressiva expansão do ativismo de diversas agências religiosas nas mais variadas arenas públicas. Partimos da hipótese de que esse modo de se apresentar em público afeta, ao mesmo tempo, nosso entendimento do que é "religião" e do que é o "espaço público". O conceito clássico de "religião" é caudatário da noção de "Igreja", que supõe a incorporação de "fiéis" em uma base comunitária mais ou menos abrangente cuja força pode ser dimensionada pela conviçcão no pertencimento e pela regularidade na frequentação aos cultos. Em consonância com a literatura mais recente sobre o tema (Beyer, 2012; Casanova, 1994), consideramos que esse conceito centrado na igreja e sua coletividade de crentes não é mais capaz de circunscrever a intensa circulação dos atores pelas mais diversas arenas e o modo como os discursos proferidos em nome da religião articulam diferentes sistemas funcionais tais como a política, o jurídico, a ciência, a moral, a domesticidade, etc. Já quanto ao conceito de "espaço público", quando aparece associado ao tema da religião, mobiliza o problema político da laicidade do Estado. Autores como Asad (2003) têm enfatizado que a definição minimalista de laicidade enquanto princípio de neutralidade e separação do Estado em relação à religião está longe de contemplar a diversidade das formas como, historicamente, essa relação se consolida. Isso porque, sob a própria bandeira da laicidade, muitos modos de associar atores religiosos, setores governamentais e opinião pública se articulam Os trabalhos que desenvolvemos recentemente (Montero, 2015) sobre a configuração recente da esfera pública no Brasil demonstraram que a "forma debate" tem se tornado, progressivamente, um dos modos canônicos dos atores religiosos se apresentarem publicamente. ${ }^{2}$ Também a presença massiva nas ruas, em marchas,

1 Este trabalho é resultado do projeto "Religião, Direito e Secularismo: a reconfiguração do repertório cívico no Brasil contemporâneo" apoiado pela Fapesp (nº 2015/02497-5) a quem desde já agradecemos.

2 Assumindo a perspectiva de Talal Asad, autores como Emerson Giumbelli $(2008,2011)$ e Ranquetat Jr. (2012) enfatizam a importância dos dispositivos jurídicos estatais para a compreensão das formas como as religiões são autorizadas a se expressar publicamente. Tomando como objeto as polêmicas em torno da presença de símbolos religiosos em recintos estatais, esses autores procuram compreender como a regulação do religioso configura a laicidade brasileira. 
caminhadas, shows e eventos em grandes estádios, assim como a multiplicação de programas televisivos mantidos por organizações religiosas, associa esse modo de se apresentar ao processo de formação das opiniões. No plano mais especificamente político já está clara a estratégia de algumas organizações religiosas de desenvolver competências para ampliar seu espaço no campo partidário e legislativo (Baptista, 2009; Machado; Burity, 2005; Mariano, 2016).

Levando em conta esses elementos, procuraremos demonstrar neste artigo como essas diversas dinâmicas de produção de visibilidade resultam em um novo entendimento do que é "fazer religião" e, no limite, modificam a configuração de nossa ordem jurídica secular. A partir da análise de alguns casos concretos, nosso foco privilegiará os processos de publicização da religião, que exigem, por um lado, o domínio de tecnologias de mobilização e engajamento de diferentes públicos e, por outro, o desenvolvimento de pedagogias de si de modo a desenvolver competências para a participação nos confrontos públicos.

\section{A religião-monumento: 0 Templo de Salomão}

Entre as inúmeras estratégias de produzir a religião em público destaca-se, pela sua ousadia e caráter paradoxal, a iniciativa recente da Igreja Universal do Reino de Deus de construir o Templo de Salomão, inaugurado em 2014 no bairro do Brás, em São Paulo. A tática pode ser considerada ousada pelo risco implicado no volume do investimento realizado (680 milhões de reais), pelas dificuldades assumidas no projeto de transplantar a Terra Santa importando de Israel pedras, tamareiras e grandes réplicas de objetos rituais e, ainda, pela ideia de inserir no panorama das edificações religiosas já conhecidas - igrejas, sinagogas, mesquitas, templos budistas - uma novidade sem equivalente na tradição recente, uma vez que os dois primeiros templos de Salomão teriam sido destruídos ainda na Antiguidade. Seu caráter paradoxal reside no fato de que, em aparente contradição com a função clássica da forma igreja, isto é, lugar de culto que "reúne fiéis em uma base abrangente e contínua" (Beyer, 2012, p. 116, tradução nossa), o Templo de Salomão se apresenta como sendo destinado "para todos os povos, independente de raça ou credo" (site oficial). É claro que, no bojo de um movimento geral recente, já reconhecido e bastante descrito pela literatura (Hervieu-Léger, 1993), de deslocamento da dominância 
do modelo igreja como arranjo institucional privilegiado da atividade religiosa, o Templo de Salomão pode ser considerado como uma expressão bem-sucedida desta nossa era do "crer sem pertencer" (Beyer, 2012, p. 120). Ainda assim, seria preciso compreender, tendo em vista a elevada aposta realizada na construção desse dispositivo em um contexto de desinstitucionalização das práticas religiosas, como ele se organiza para exercer influência pública. Para abordar esse tema, desenvolveremos nosso argumento em torno de duas grandes questões: a primeira, que será enfrentada pela análise da cerimônia de inauguração do complexo, diz respeito ao modo como o Templo de Salomão reivindica publicamente sua função religiosa inserindo-se na paisagem urbana paulistana e ao tipo de visibilidade que ele produz; a segunda, que dará atenção às formas de ação social a partir das quais ela se apresenta como religião, procurará compreender seu desempenho e alcance fora do âmbito estritamente cultual. ${ }^{3}$

\section{O Templo de Salomão em cena}

A cerimônia inaugural do Templo de Salomão da Igreja Universal do Reino de Deus (Iurd) em 2014, que encerrou os quatro anos de sua construção, foi cuidadosamente planejada para produzir grande impacto midiático, espetáculo cujo efeito esperado é o ganho em visibilidade. ${ }^{4}$ Pela leitura do noticiário da época pode-se afirmar que essa estratégia foi relativamente bem-sucedida. Com maior ou menor entusiasmo, nenhum dos principais jornais, redes de televisão

3 Estamos usando os conceitos de função e desempenho tal como foram propostos pela leitura empreendida por Peter Beyer (1998, p. 401) a respeito da teoria de Luhmann sobre a secularização. Segundo Beyer, essa distinção luhmaniana diz respeito ao modo como um subsistema funcional se remete à sociedade como um todo (função) e ao modo como ele se relaciona com outros subsistemas funcionais (desempenho).

4 Trabalhos clássicos como o de Daniel J. Boorstin (2012), Le triomphe de l'image, de 1962, levantaram o problema dos pseudoeventos que têm por objetivo não informar, mas produzir visibilidade. Seu trabalho denuncia o reino do simulacro e do artifício que passou a dominar os meios de comunicação. Nossa intenção neste texto, no entanto, não é "desmascarar" as estratégias midiáticas de busca de credibilidade promovidas pela Iurd, mas procurar compreender os modos como instituições religiosas produzem a forma "religião" por meio da visibilidade conferida pelos eventos de mídia. Para tanto temos privilegiado não tanto o conceito de imagem e seus modos de representação, mas, sobretudo, o de performance, que deslocou-se do campo das artes para a totalidade do campo de comunicação. Inspirados em autores como M. José Mondzain, colocamos sob o foco de nossa análise a mise-en-scène em sua relação com o tempo real, o engajamento dos corpos e o lugar do espectador. 
e agências deixaram de mencionar o evento. Como calibragem especial de sua importância estava o peso político das autoridades que atenderam ao convite: a então presidente da República Dilma Rousseff e seu vice Michel Temer, o governador Geraldo Alckmin e o prefeito Fernando Haddad, mais de 12 governadores de Estado, Ricardo Lewandowski representando o Superior Tribunal Federal, Elizabeth Rocha, presidente do Supremo Tribunal Militar, os presidentes da Assembleia Legislativa e do Tribunal de Justiça, o procurador-geral de Justiça e membros do Ministério Público, desembargadores e muitos outros representantes do Judiciário. Também estava presente o representante da Confederação Israelita do Brasil, Claudio Lottenberg. Em vista desta lista, mesmo incompleta, devemos nos perguntar em que circunstâncias a inauguração de um complexo religioso é capaz de convocar para um evento os mais altos representantes da função estatal. Ao lado disso, pelo fato de Edir Macedo, fundador da Iurd, ser também proprietário de uma emissora de televisão, a rede Record, foram também mobilizadas algumas "celebridades" de relativa grandeza, que concederam entrevistas e repercutiram a notícia em suas redes e programas, tais como os apresentadores Sabrina Sato, Gugu Liberato, entre outros. Finalmente, pelo modo como o mestre de cerimônia conduziu o evento pode-se inferir que os dez mil lugares sentados estavam ocupados prioritariamente por pastores, bispos e seus convidados. ${ }^{5}$ Essa qualificação do público presente demonstra como a função culto religioso encenada na ocasião, ou a comunicação que se apresenta como propriamente religiosa, foi exercida de modo articulado com a função mediática e política. Essa mesma configuração aparece, como veremos a seguir, na estrutura narrativa da performance ritual apresentada. Com efeito, uma breve descrição etnográfica das estratégias de ritualização adotadas nessa cerimônia, tal como ela pode ser acompanhada em registro visual no YouTube, nos permitirá desvendar, em suas grandes linhas, os padrões que conformaram a apresentação pública da Iurd nesse evento e para esse público.

5 Segundo relato da jornalista Laura Caprilione (2014), os convidados recebiam um convite em pergaminho pelo correio acompanhado de um envelope com uma senha. Com ela o convidado acessava o site e se cadastrava inscrevendo seu RG. O cerimonial ligava em seguida para confirmar os dados e então vinha um cartão com um código de barras. Esse cartão só seria aceito na portaria do evento mediante a apresentação de documento com foto. Então o convidado recebia um pin colorido que o classificava em ordem de importância, dirigindo-o as cadeiras correspondentes. 
Embora não seja possível descrever aqui a cerimônia de um pouco mais de três horas de duração, procuraremos ao menos examinar sua estrutura narrativa de maneira a compreender, ao mesmo tempo, de que modo a cerimônia se dirige para a sociedade como um todo e como articula rito, cultura, ação social e política. Observada em seu conjunto, pode-se perceber que a forma espetáculo - uma vez que é disso mesmo que se trata, uma sucessão de linguagens musicais, fílmicas, orais e gestuais encenadas em um palco e no espaço do edifício para um grande público - foi estruturada em dois grandes blocos: no primeiro, a personagem central é uma réplica ampliada da Arca da Aliança e sua entrada triunfal no templo; no segundo, a fala dos pastores. Chama nossa atenção que, para um espaço que se apresenta como "não tendo bandeira nacional", tenham sido executados, separando os dois blocos da encenação, os hinos nacionais de Israel e Brasil. Tendo em vista que não poderemos empreender, neste texto, uma análise da cerimônia na sua totalidade, concentraremos nossa atenção na primeira parte, de modo a compreender o modo como a cerimônia procurou maximizar a eficácia de sua comunicação religiosa apresentando-se como uma experiência de Deus para todos.

A Arca da Aliança, e sua verdadeira localização, é até hoje objeto de acalorado debate no mundo religioso judaico. De sua descoberta, muitas vezes anunciada e desmentida por arqueólogos, rabinos e comentadores, dependeria a fundação do Terceiro Templo de Salomão em Israel. Na estratégia de ritualização adotada na cerimônia de inauguração do templo em São Paulo escolheu-se fazer do ritual de entronização de uma réplica da Arca da Aliança o elemento central e apoteótico da sacralização do enorme edifício situado no Brás. Vídeos, projetados na fachada do edifício, o associam às construções originais do templo por Davi e seu filho Salomão, ciosos em oferecer à arca uma morada divina. Tapetes vermelhos, gestos ensaiados, vestimentas especiais, música e clarins, contribuíam para compor uma atmosfera extraordinária e transformar a cena em um drama ritual da emergência do sagrado. Alguns elementos chamam a atenção de quem assiste a esse trecho da encenação nos vídeos circulados pela Iurd. Em primeiro lugar, a sensação de estranhamento causada nos espectadores diante da exibição de tantos elementos sagrados tão pouco familiares para o grande público. Homens vestidos com túnicas de seda branca e grandes cinturões dourados carregavam, marcando seus passos com uma marcha cadenciada, um grande baú dourado. Diante da patente ignorância de um dos narradores com relação ao significado do que estava sendo apresentado, "para mim é tudo 
uma novidade", dizia ele, uma outra apresentadora explicava didaticamente aos telespectadores o sentido de cada detalhe: a arca abriga as Tábuas da Lei oferecidas por Deus a Moisés, os grandes querubins dourados que encimam a arca garantem sua segurança, seus portadores são os levitas, sacerdotes do antigo templo, a arca representa o próprio Deus entre os homens, etc. Os narradores enfatizavam ser aquele evento "algo exclusivo nunca visto antes", pontuavam a marcha com exclamações do tipo "olha que impressionante", "o coração está batendo forte", "é uma experiência muito boa com Deus".

Em seu trajeto, a arca saiu da antiga sede regional da Iurd, também situada na avenida Celso Garcia, e percorreu em marcha cadenciada um trajeto relativamente curto até os portões do gradil que cerca o Templo de Salomão. Parte da imprensa reclamou não ter sido convidada a assistir ao evento e criticou o impressionante paredão de pessoas com camisetas brancas com a estampa do templo em dourado que, de mãos dadas, isolavam o edifício da curiosidade dos pedestres e repórteres e procuravam deixar a via livre para a chegada dos convidados, rigorosamente controlados na portaria do prédio.

Transpostos os portões de ferro, a arca entra "triunfalmente", segundo a narradora, na grande esplanada do edifício ao som do tema do casamento de Moisés, hit da novela da Record Os dez mandamentos. Doze clarins anunciam sua chegada. Diante dos portões do santuário, o manto que recobre a arca é retirado e dobrado ritualmente por dois levitas "de uma forma muito respeitosa, não de qualquer maneira", pontua a apresentadora, que exclama: "Agora sim vamos poder ver a arca!" Tocam novamente os clarins, abrem-se as quatro grandes portas douradas do templo ladeadas por oito levitas. A arca entra no átrio e as quatro portas douradas são fechadas cerimoniosamente. Outras quatro portas douradas, que dão acesso à nave central, são abertas. "Agora sim!", exclama a apresentadora "[...] podemos acompanhar a entrada dos sacerdotes levando a Arca da Aliança para dentro do santuário do Templo de Salomão." “Uma beleza! Indescritível!!”, completa o narrador. Os convidados se põem de pé. A arca percorre com a mesma marcha a nave central do santuário até o altar. "A entrada da arca representa a entrada de Deus na vida das pessoas", pontua a narradora. Passando diante do altar incrustado com 12 pedras coloridas, que representam as 12 tribos de Israel, a arca desaparece atrás das cortinas e é guardada. "Nós brasileiros tivemos essa chance, esse privilégio que Deus nos deu, de termos o Tempo de Salomão em São Paulo, Brasil" conclui o apresentador. 
Esse pequeno fragmento etnográfico da cerimônia de inauguração tal como foi gravado em DVD pela equipe do templo, ${ }^{6}$ embora demasiadamente sucinto, nos oferece alguns elementos para que possamos responder as questões gerais que aqui nos interessam. A primeira diz respeito às circunstancias desse evento que permitiram produzir a poderosa imagem de um segmento importante da cúpula dirigente do país se colocando de pé em respeito a um símbolo religioso pouco tradicional no repertório nacional. Cerimônias anteriores, como a inauguração da imponente Catedral Mundial da Fé, em 1999 no Rio de Janeiro, não tiveram o mesmo reconhecimento oficial. Tirante o fato que em 2014 estavam previstas eleições majoritárias - o que, evidentemente, atraiu os potenciais candidatos - chama nossa atenção a significativa presença de representantes do Legislativo e do Judiciário. Nesse sentido, para além das questões eleitorais, é possível afirmar que o modo como foi produzida a religião nesse ritual permitiu que a ação política e a ação religiosa se engajassem mutuamente sem suscitar grandes controvérsias. Os políticos atenderam ao convite de inauguração de um luxuoso equipamento urbano implantado em zona carente, os religiosos apresentaram seu poder de arregimentação das massas por meio do espetáculo do sagrado, estamentos do Judiciário deram seu aval ao arranjo. Com efeito, quando observamos as particularidades de sua produção, pode-se perceber que o evento foi concebido nos moldes de um espetáculo comercial privado e não como uma cerimônia religiosa. O modo como os convites foram enviados, as "celebridades" presentes, a magnificência do edifício a ser inaugurado, tudo convergiu para a dissolução da ideia de que se tratava de prestigiar/participar de um culto. Por outro lado, é de se notar que o edifício não ostenta nenhum dos símbolos que até recentemente marcaram a trajetória da Iurd, tais como a pomba e os dizeres "Jesus é Meu Senhor". As letras góticas de sempre deram lugar aos dizeres "Santidade ao Senhor" em letras do alfabeto hebraico. Essa clara ruptura com o padrão arquitetônico anterior, e a apropriação ostensiva dos signos judaicos nas vestes e nos objetos, faz do templo um complexo híbrido, nem uma sinagoga, nem uma igreja, que evoca um fazer religioso pré-cristão no qual a edificação de templos expressava a relação pessoal dos poderosos com seus deuses favoritos (Veyne, 2007). A isso se acresce

6 A cerimonia também pode ser acompanhada no YouTube (cf. https://www.youtube.com/ watch?v=SMb4wJRtDzU). 
o relativo apoio da comunidade judaica brasileira, que se sentiu lisonjeada com as referências judaizantes do templo e com a apresentação do hino nacional de Israel no evento. Na interpretação de Rodrigo Franklin de Souza, professor de Ciências da Religião da Universidade Presbiteriana Mackenzie, essa forma de reinventar a religião indicaria uma "tentativa de alcançar [...] pessoas que teriam certa vergonha de ir à Universal para não serem estigmatizadas" (Shalom, 2014). Em nota oficial, a Iurd informa que o Templo de Salomão "não é da Universal e sim um templo universal - para toda a humanidade, de todas as raças e credos, para qualquer pessoa que quiser conhecer o Deus da Bíblia. Para a Universal, o significado do Templo é totalmente espiritual" (Shalom, 2014). Nessa nova forma de apresentar sua função social de modo a oferecer um serviço para todos, o templo - evocação de tempos desaparecidos - procura construir para si um lugar fora e além da religião. O que nos parece paradoxal nessa estratégia universalista de ganhar visibilidade é que ela não parece ter como consequência a produção de espaços públicos, civis. Mas, ao contrário, a própria produção do evento e sua execução nos indicam que o espaço do templo, embora procure não apresentar-se como religioso, produz o espetáculo de sua sacralização em um acontecimento privado, controlado pelos seus idealizadores e tornado público pela mediação dos meios de comunicação e propaganda.

\section{A religião-manifesto: forma de publicização das Igrejas da Comunidade Metropolitana}

Visibilidade também é questão central para as Igrejas da Comunidade Metropolitana (ICM), braço brasileiro da Metropolitan Community Churches, organização religiosa fundada em 1968, em Los Angeles, nos Estados Unidos. Trata-se de uma instituição que tem como objetivo congregar populações que estariam impedidas de ter uma vida comunitária cristã devido a, principalmente, questões morais relacionadas a gênero, práticas e identidades sexuais não convencionais.

Organizada em torno de pequenos núcleos que raramente excedem 40 pessoas em seus cultos dominicais - a maioria homens que se identificam como gays, entre porções menores de lésbicas e pessoas trans -, as aparições cada vez mais frequentes da ICM em diversas mídias nacionais contrastam 
com a pequena extensão da sua rede de fiéis, mesmo quando comparada a outras ditas igrejas inclusivas, isto é, instituições religiosas, que, grosso modo, concorrem pelo mesmo tipo de público, pelo menos no que diz respeito às orientações sexuais e identidades de gênero. Em uma operação comunicativa que a produz enquanto uma igreja-símbolo de múltiplas causas, essas participações em peças midiáticas acabam tendo dupla serventia para a organização: 1) lhe conferem relevo público para além do reduzido tamanho das audiências que se formam em torno das suas arenas de culto e 2) lhe conferem uma forma específica e bem contemporânea de se viver a religião, isto é, encarnando-a publicamente.

É importante ressaltar que esse regime específico de publicização do religioso necessita ainda ser mais bem descrito e compreendido. O caso da ICM no Brasil é particularmente interessante porque nos dá acesso a uma configuração bem específica desse fenômeno. De um lado, temos agentes religiosos marcados por uma disposição à publicização, expressa na chave do acolhimento cristão, que se atualiza em uma política de visibilização de práticas e identidades tidas como segregadas e apregoada verbalmente inclusive nos cultos. Do outro, temos agentes como jornalistas, documentaristas e estudantes interessados em apresentar ao grande público o projeto religioso dessa igreja e/ou alguns aspectos relacionados à trajetória de suas lideranças. Ambos os tópicos são alçados à condição de notícia por serem enquadrados enquanto objetos informacionais inéditos e sui generis e, ao mesmo tempo, por informarem algo a respeito de uma dada posição nas contemporâneas controvérsias públicas sobre gênero e sexualidade.

Assim como outras organizações religiosas que vêm se destacando na cena pública por conta dos seus novos modelos e práticas de regulação da vida íntima calcados em pedagogias de gênero (Teixeira, 2014, 2016), a ICM coloca em ação formas específicas de fazer religião indissociáveis da produção e circulação daquilo que estamos nomeando como discursos trípticos. Como no caso anterior descrito acima, nessas falas “teológicas", as instâncias do político, do religioso e da sexualidade ${ }^{7}$ coexistem para afirmar uma unicidade semântica,

7 É importante esclarecer que estamos tratando sexualidade como categoria abrangente, que articula desejo, performances de gênero e práticas sexuais, bem como os regimes regulatórios que inter-relacionam essas dimensões e as hierarquizam. 
embora o desempenho da comunicação religiosa reafirme sua independência com relação aos outros sistemas funcionais.

Para descrevermos analiticamente essas novas formas de "fazer religião em público", tomaremos como referência o caso da pastora transgênera Alexya Salvador. ${ }^{8}$ Como no relato do Templo de Salomão, também nesse caso nos interessa compreender como a comunicação religiosa se articula ao ativismo social formulando uma discursividade que extravasa o âmbito estritamente cultual. Em função da configuração da ICM acima descrita, nossa análise se desenvolverá em dois níveis: o primeiro diz respeito ao modo como a representação da biografia de Alexya é apropriada pelos meios de comunicação como notícia para produzir um discurso que se dirige para a sociedade como um todo; o segundo se refere às tecnologias do relato de si que essa personagem utiliza para produzir a representação de sua causa na cena pública (Butler, 2015).

Não estão no foco deste texto análises sobre os discursos jornalísticos e os modos como essa organização religiosa vem vendo representada pelas mídias. Contudo, privilegiaremos o acesso a alguns desses conteúdos para situarmos um dos argumentos centrais desta análise: por meio da observação de práticas comunicativas circunstanciais de determinados agentes, que se associam coletivamente em nome daquilo que eles descrevem como sendo "a religião" e/ou "o religioso", podemos identificar e analisar as estratégias de bricolagens discursivas (Hervieu-Léger, 2008) que produzem, em público, as fronteiras do que é ou não é religioso.

8 Mulher transgênera é a forma com que Alexya se identifica e gostaria de ser identificada. A transgeneridade remete à possível condição de pessoas assumirem identidade de gênero, seja feminina ou masculina, diferente daquela que concordaria, segundo norma, com as suas características biológicas. Importante salientar, contudo, que a remissão a uma classificação, por consequência, ao seu sistema classificatório, não visa produzir uma estabilização do nosso sujeito focal. Isto é, não almejamos uma categoria que sirva como chave para a verdade de Alexya. A transgeneridade, bem como outros termos com os quais estabelece relações dentro de um mesmo campo semântico (transexualidade), é uma categoria ainda em disputa e atravessada por tensão de saberes e poderes de diversos campos, inclusive o médico, que inscreve, descreve e visa gerir essa dada manifestação no quadro discursivo da disforia de gênero. Alexya está mais do que informada pelo debate. Como veremos adiante, ela transforma seu processo de nominação, que ilumina a forma como ela visa repensar o modelo de família e as regras para estabelecimento de parcerias afetivas e sexuais, não só no seu campo de lutas objetivas. Tornar-se a pastora transgênera é também seu campo de descobertas, reinvenções e desconstruções. 


\section{A pastora transgênera em cena}

"Minha vida é dos meus filhos': pastora trans fala sobre ser mãe". É com essa chamada que o portal Catraca Livre abriu no dia 5 de maio de 2017 a sua série de reportagens "Mães que TRANSformam (Minha..., 2017). Em entrevista conduzida por Jonas de Carvalho, Alexya Salvador, recentemente ordenada como a primeira pastora transgênera da ICM da América Latina, relata sua experiência com a maternidade, refletindo sobre a relação que vem sendo construída por ela, seu marido e seus dois filhos adotivos, Gabriel, um garoto com necessidades especiais, e Ana Clara, uma menina transgênera.

Na versão transcrita da entrevista, a presença do elemento religioso é diminuta. Exceto pelo fato de que a função social incomum de pastora trans é destacada no título e na abertura do texto, o entrevistador não tece indagações relacionadas às posições e funções religiosas da entrevistada. Alexya apenas tangencia a questão quando, respondendo a pergunta sobre o que a maternidade estaria lhe ensinando, diz que, ao estar sendo impelida a ser uma pessoa cada vez melhor, ela estaria sendo um exemplo para os filhos, "e também para as pessoas que me cercam, mesmo aqui na igreja".

No entanto, quem assiste ao vídeo da entrevista, disponível na mesma página, entende que, para aquela peça de comunicação, o religioso é, embora subliminar, quase absoluto. Alexya dá seu depoimento emoldurada pelo altar da igreja onde ela se tornou a partir de 2017 pastora auxiliar, após ter concluído curso de teologia a distância na Faculdade Unida de Vitória e formação no Instituto Darlene Garner, um centro de formação de lideranças latino-americano fundado pela Metropolitan Community Churches. Escolhido como cenário, o ambiente da igreja confere sentido e dramaticidade especiais às falas de Alexya, como indicam as tomadas e closes na cruz de madeira ao estilo céltico, enquanto a entrevistada fala em off sobre a vivência prática do amor incondicional, por exemplo.

Outros portais de notícias e blogs também noticiam sua trajetória, publicizando metonimicamente suas causas e, em particular, sua retórica. "Nasci para ser mãe', diz pastora trans Alexya Salvador que adotou menino especial e menina trans", anunciou em janeiro de 2017 o blog do jornalista Neto Lucon (2017). “'Sempre quis ser mãe': pastora trans adota criança também trans", repercute o site iGay (Fontes, 2017) reproduzindo trechos da reportagem 
de Neto Lucon. "Sou mulher transgênera, pastora e mãe de duas crianças", assim intitulou Helena Bertho (2017) a sua reportagem publicada no site de notícias UOL no dia 31 de março do mesmo ano.

Alexya também foi personagem de reportagens especiais dos canais GNT e RedeTV!, deu depoimento em matéria sobre novas configurações de família no Globo Repórter, revista eletrônica veiculada pela Rede Globo, e esteve presente em documentários, como Fé em atos (2017), produzido e dirigido por Júlia Pellizon. Sua trajetória e fala já foram inclusive abordadas academicamente por meio da tese em História Social (Re/des)conectando gênero e religião. Peregrinações e conversões trans* e ex-trans* em narrativas orais e do Facebook, de Eduardo Meinberg Maranhão Filho (2014), defendida em 2014, na Universidade de São Paulo.

A visibilidade internacional foi obtida a partir de reportagem publicada no dia 7 de maio no portal da agência de notícias Reuters, que noticiou a participação de Alexya no primeiro culto trans promovido em uma igreja cristã em Cuba. Intitulado "Communist-ruled Cuba hosts first transgender Mass", o texto de Sarah Marsh e Anett Rios (2017) foi reproduzido, traduzido ou adaptado para ser veiculado em diversas outras mídias como o inglês Independent (Buncombe, 2017), o site G1 do Grupo Globo (Pastora..., 2017), a página de notícias portuguesa P3 e demais órgãos de informação em outras línguas como o espanhol e o francês.

No que diz respeito às técnicas de apresentação de si, em suas posições teológicas, Alexya aproveita o suporte das mídias para veicular mensagens religiosas pouco convencionais como a declaração produzida pela reportagem da Reuters: "God's love is radically inclusive" (Marsh; Rios, 2017). Recorrendo à Bíblia como fonte de autoridade, na apresentação de si em público, ela reitera continuamente a citação bíblica "Deus não faz a acepção de pessoas". ${ }^{9}$ A seu ver, sua trajetória pessoal seria a prova dessa verdade; para torná-la pública e contribuir para romper a espiral do silêncio (Noelle-Neumann, 1984) em torno de uma espiritualidade que estaria além de uma moralidade heteronormativa, faz da apresentação de si em diversas mídias o instrumento dessa narrativa.

9 Referência à passagem bíblica “E, abrindo Pedro a boca, disse: Reconheço por verdade que Deus não faz acepção de pessoas" (Atos 10:34). 
Assim como muitas histórias sobre o gênero trans, ainda criança Alexya se sentia diferente. Ela, que nasceu e reside até hoje em Mairiporã, região metropolitana de São Paulo, foi criada em um ambiente familiar muito unido, conservador e católico. A pastora, porém, acabou encontrando na fé um refúgio paradoxal para sua identidade de gênero que a confundia e a afligia desde que se conhece por gente. Ao mesmo tempo em que encontrava conforto na religiosidade, também temia estar cometendo um pecado mortal aos olhos de Deus - por não se sentir de acordo com as normas da igreja. (Declercq, 2017).

É contribuindo para a produção de textos construídos em torno de relatos biográficos como esse e fazendo-os circular para além das paredes da pequena igreja hospedada em uma sobreloja no bairro paulistano da Santa Cecília que Alexya vive na prática o seu ativismo político e religioso. São essas peças de comunicação que multiplicam suas falas para além das pequenas arenas da ICM, discursos em contínua elaboração e transformação. Uma das suas mais recentes formulações teológicas, inclusive destacada no texto da Reuters, diz respeito à existência de uma espécie de radical semelhança entre a sua condição espiritual e a divina. "Jesus Cristo foi o primeiro homem trans", explicou com mais detalhes para Marie Declercq (2017), autora do texto citado acima.

Te explico [disse a Declercq]. Nós aprendemos desde o Gênesis que existe a Santa Trindade: o Pai, o Filho e o Espírito Santo. Deus, portanto, mandou seu filho para a terra. Jesus, o filho, tinha o gênero divino, correto? Então, quando ele desceu para a terra ele passou a ter o gênero humano. Então, se Jesus pode se transicionar, por que eu não posso?

Esse e outros textos tornados públicos por diversas mídias atestam que Alexya assumiu posição em múltiplas controvérsias, algumas sobrepostas, outras necessariamente não coincidentes, tais como: a aceitação de uma espiritualidade para além da heteronormatividade; legitimidade das relações afetivas e sexuais não binárias; legalidade da transmaternidade. A reportagem publicada no dia 13 de setembro pela revista Veja São Paulo ilustra algumas delas: "Formada em letras e pedagogia, ela começou a transformação (transição de gênero) há seis anos. Na época, já era casada com Salvador. 'Meu marido é homossexual e me conheceu como Alexander. Tinha medo que ele não me aceitasse após me 
expressar como mulher"', comenta para a reportagem escrita pela dupla de jornalistas Ana Carolina Soares e Rosana Zakabi (2017), inspiradas pela repercussão nacional de Ivana, a personagem transgênera da novela $A$ força do querer, da Rede Globo. ${ }^{10} \mathrm{O}$ marido, também professor e membro da ICM, "não apenas continuou o relacionamento, como topou a ideia de adotar filhos", continua o texto.

Primeiro, veio Gabriel, em 2015. Um ano depois, Ana Maria, que é transgênero como a mãe. "Posso passar toda a minha experiência para ela." Há três anos, Alexya começou a costurar e hoje vende aventais de professores e roupas em geral. "Meu objetivo agora é abrir uma confecção voltada para o público trans", planeja. (Soares; Zakabi, 2017).

É por meio de inserções midiáticas como essa que Alexya deliberadamente participa de uma batalha simbólica na qual se disputa, antes mesmo da plausibilidade e legitimidade dos seus sentidos enunciados, a sua visibilidade, nesse caso, sua inclusão no espaço da fala pública. Sua participação nessas controvérsias implica tanto a deliberada enunciação de discursos tradicionalmente silenciados como a divulgação da igreja e dos seus discursos pastorais. Desse modo, em uma única operação de produção de visibilidade, a função religiosa e a função política se tornam termos convergentes.

Contudo, a reportagem “'Professora, você é homem?' A vida de uma mulher trans na sala de aula", de Ingrid Fagundez (2017), publicada no dia 15 de agosto de 2017 no site da BBC Brasil, nos ajuda perceber que não se trata da construção de um simples novo personagem religioso. O que as sensibilidades jornalísticas orientadas ao ineditismo estão captando são os reflexos de novos regimes de modelagem de sujeitos política, erótica ${ }^{11}$ e teologicamente encarnados em corpos civis e sexuados cuja produção já foi abordada em trabalhos anteriores (Silva, 2015, 2016, 2017; Teixeira, 2014). E, nessa operação, é interessantíssimo

10 Alexya foi retratada no box "Fé na diversidade", que integra a matéria de capa "As 'Ivanas' da vida real" (Soares; Zakabi, 2017). A chamada de capa foi: "A vida além da novela".

11 Sujeitos eróticos, assim como sujeitos políticos ou teológicos, nos remetem a articulações entre sistemas de saber/poder, como bem estabeleceu Foucault (1988). No âmbito do erotismo, isso implica as regulações dos regimes de prazer, que estão vinculadas, como bem apontou o mesmo autor (Foucault, 1984), à ciência do prazer. É o seu objeto/projeto que dá os contornos daquilo que se nomeia enquanto erótico. 
observar que imaginações teológicas incidem sobre imaginações sociológicas e vice-versa, configurando sempre específicos erotismos cosmologizados a serviço de um projeto civil.

O texto resultante do desejo de representação partilhado entre a jornalista Ingrid Fagundez (2017) e a pastora Alexya é eloquente:

A história de Alexya é também a de sua família, símbolo da diversidade que defende. Roberto é gay, Gabriel, hétero, Ana Maria, trans. Quatro pessoas de cantos diferentes que decidiram "cuidar umas das outras", segundo a definição da matriarca. E que se unem em uma coisa só no momento da hóstia quando, crianças no colo dos pais, se abraçam, cabeças encostadas e olhos fechados.

Em outro trecho, cravejado por termos oriundos do cabedal católico que não pertencem ao universo das práticas da ICM, o ideal comunitário da instituição é reconhecido, destacado e chancelado pela repórter:

Em uma das missas da Igreja da Comunidade Metropolitana, onde seus filhos vão todos os domingos para ouvir os sermões, fala sobre a liberdade do ser. Trans, gays, lésbicas, bissexuais, travestis e drag queens ocupam as fileiras. Jesus aceitava a todos da forma como eram, diz nas pregações, então não nos cabe julgar. Mas ressalta que a ICM não se resume ao filho de Deus. (Fagundez, 2017).

É a pastora quem, no texto, ganha espaço para conferir sentido político àquela particular articulação teológico-moral da sexualidade:

Hoje é [a ICM] conhecida mundialmente como a igreja dos direitos humanos, porque não queremos só ficar falando de Jesus. A gente quer ir para as frentes de batalha, para o Senado, para o Congresso, quer dizer que, se a mulher quiser abortar, o corpo é dela. Não vou legitimar sua vida, você legitima sua história. (Fagundez, 2017).

Assim Alexya traça o breve perfil das Igrejas da Comunidade Metropolitana, que analiticamente também podem ser enquadradas enquanto arenas de comunicação, seguindo a trilha das proposições pragmáticas de autores como Cefaï (2009, 2012) e Quéré (2003). Apesar de pequenas comunidades pulverizadas 
por alguns estados brasileiros, ${ }^{12}$ juntos, esses núcleos vêm modelando, a partir de experiências colocadas em práticas por agentes situados como Alexya, uma específica forma de combinar vida comunitária estabelecida por conta de laços religiosos com múltiplas formas de ativismo social, sempre ancorado em meios metalinguísticos de publicização de suas causas. Isto é, publicizar uma causa é colocá-la em cena vivendo-a publicamente.

Seguindo trilha sugerida por Butler (2015) em sua discussão acerca das tecnologias do relato de si, tais igrejas-comunidades também poderiam ser encaradas como tecnologias para sujeitos reaprenderem e praticarem, num tempo e espaço circunstanciado, uma nova retórica de si. Darem, enfim, sentido à vida e ao seu entorno a partir da educação de uma nova regra de enunciação de si a ser exercida em dois âmbitos que se sobrepõem na experiência: o íntimo e o público. Isto é, não basta simplesmente se descobrir ser. É necessário experimentar essa existência sendo reconhecido publicamente. É o "to come out" experimentado como uma vivência religiosa a duplicar o sentido da categoria "libertação".

\section{A religião-debate: controvérsias sobre o início da vida no STF}

As intervenções das religiões em questões consideradas de interesse público têm sido marcadas pelo confronto, ou mesmo pelo conflito. Estudos recentes têm demonstrado que, no atual contexto de pluralismo religioso, as tentativas de interferência das instituições religiosas em questões políticas ou jurídicas não são mais consensuais, passando sempre, ao contrário, pela via do dissenso. No caso brasileiro, o declínio da hegemonia da Igreja Católica nos últimos 50 anos tem produzido modificações em suas estratégias de disputa pela influência pública. Historicamente, o catolicismo, com sua forte presença institucional e força simbólica, ocupava posição-chave como agência reguladora da vida social, fomentadora de formas de mobilização e construção de uma cultura cívica e de uma moralidade pública. Valendo-se de sua tradicional proximidade com a máquina do Estado e da naturalização dos valores católicos como cultura

12 As Igrejas da Comunidade Metropolitana atualmente estão presentes nas cidades de Maringá (PR), São Paulo, Rio de Janeiro, Belo Horizonte, Vitória, João Pessoa, Cabedelo (PB), Fortaleza e Teresina. 
nacional, as lideranças católicas tendiam a lançar mão de uma discursividade mais dogmática e teológica para defender seus posicionamentos político-morais.

Até muito recentemente os valores presentes na esfera pública brasileira eram coadunantes com os valores do catolicismo. Entretanto, mais recentemente o "consenso" católico passa a ser questionado, como mostra uma série de ações levadas aos tribunais (Montero, 2015; Sales, 2015). Com efeito, no contexto dos sistemas democráticos pluralistas, a judicialização do dissenso passa a implicar a necessidade de justificar razões e mobilizar públicos para que se possam produzir consensos legais em torno das opiniões. Essa nova forma de atuação via o debate público tem obrigado os atores religiosos a abandonar defesas doutrinárias e dogmáticas e a levar em conta convicções religiosas e não religiosas divergentes. Além disso, como bem demonstraram os trabalhos em Cefaï e Pasquier (2003), as regras implícitas que regem a forma do debate também sofrem os constrangimentos das arenas nas quais eles se desenvolvem, tais como as arenas jurídicas, acadêmicas, mediáticas, governamentais, etc. No caso da arena jurídica que aqui nos ocupa, elementos teológicos não têm poder de convencimento: para se tornarem verossímeis os argumentos precisam ser construídos com base nas gramáticas em jogo e em disputa nessa arena, tais como a gramática acadêmico-científica e a dos fundamentos do indivíduo moderno. Assim veremos que, para se tornarem convincentes, as demandas e convicções apresentadas nos casos aqui analisados foram apresentadas na linguagem pública adequada à arena jurídica na qual a controvérsia se desenrolava, e as narrativas foram ancoradas nos termos e nos elementos das gramáticas em jogo nessa arena.

Tomamos como referência duas ações julgadas pelo Superior Tribunal Federal nos anos de 2008 e 2012. A primeira delas diz respeito a ADI 3510, realizada pelo procurador-geral da república Cláudio Fonteles, reagindo contra o artigo quinto da Lei de Biossegurança, que permitia o uso de células-tronco embrionárias em pesquisas científicas. A ação foi a julgamento no Supremo Tribunal Federal em maio de 2008. Essa controvérsia, e a constelação de argumentos que a constituiu, foi também explicitada na audiência pública convocada pelo STF em abril de 2007.

A segunda refere-se ao julgamento da ação que permitiu a interrupção da gestação em mulheres grávidas de fetos anencéfalos (ADPF 54). O ministro Marco Aurélio Mello havia deferido em 2004 uma liminar que permitia a antecipação terapêutica do parto em casos de anencefalia. Essa liminar foi revogada 
em menos de quatro meses, e o caso voltou a julgamento no ano de 2012, sendo também antecedida de uma audiência pública.

Analisaremos como, nesses formatos, a "comunicação propriamente religiosa", nos termos de Peter Beyer (1998), ao disputar a opinião pública, pleiteia nessa arena o direito de se apresentar como único e último bastião da defesa da vida, uma vez que está suposto que, nem o conhecimento científico nem o conhecimento jurídico são capazes de garanti-la.

\section{O debate sobre a vida em cena no STF}

Os dois julgamentos foram precedidos por intensos debates públicos, mobilizando agentes de diferentes áreas nos dois polos da discussão: favoráveis ou contrários à liberação das pesquisas com células-tronco embrionárias e/ou à antecipação do parto de anencéfalos. Ambos foram antecedidos por audiências públicas realizadas pelo STF. Na primeira audiência foram escalados 22 cientistas, 11 representando posicionamentos "pró-pesquisa" e outros 11, "pró-vida". Já no caso do julgamento da interrupção de gravidez de fetos anencéfalos não houve paridade entre os representantes pró e contra a liberação. Foram ouvidos representantes de diversas entidades da sociedade civil, órgãos representativos de classe e instituições ligadas a denominações religiosas, havendo 18 manifestações favoráveis à ação e 11 manifestações contrárias. ${ }^{13}$

Considerando os casos dos julgamentos dessas ações como um exemplo que ilustra uma das diferentes formas de produção da religião em público,

13 Estes dados vêm sendo reunidos desde 2011, quando acompanhamos a discussão sobre as células-tronco embrionárias na mídia, identificando atores e argumentos colocados em discussão na arena pública midiática. Fizemos o levantamento e a análise dos artigos e notícias publicados em jornais e revistas de grande circulação nacional no período em que essa ação tramitou no STF. Com base nessa primeira parte da investigação, constatamos a importância do argumento "em defesa da vida humana", bem como a centralidade de alguns atores nas controvérsias. Esse mesmo levantamento foi realizado na análise da controvérsia em torno da ADPF 54. Em seguida, partimos para a identificação dos atores, feita a partir do cruzamento de informações: pela sua presença recorrente na mídia, sua repetição nas audiências públicas e sua participação em eventos e instituições vinculados à Igreja Católica. Para a escrita deste artigo foram levadas em conta especificamente as cenas das duas audiências públicas, e as exposições proferidas durante elas - que acompanhamos on-line pelo Canal Justiça -, a partir das quais observamos a composição das justificativas enunciadas nessa arena específica, e a sua articulação com argumentos e posições mais gerais nas controvérsias analisadas. 
analisaremos o formato da "comunicação religiosa" emitida pelos agentes vinculados à CNBB e/ou à Igreja Católica nessas controvérsias para fundamentar sua posição contrária às ações. Como nos casos analisados acima, o debate põe em funcionamento as mesmas dinâmicas de visibilização da religião: confere-lhe um público para além daquele que se forma em torno da Igreja e uma forma específica de experimentar a religião, que passa pela participação como audiência em sua encenação pública. Mas, nesses casos, o regime de visibilização sofre os constrangimentos das regras da arena jurídica que, pelas características de sua encenação, tornam claro para o público que as posições religiosas sobre o tema representam apenas mais uma opinião, entre outras, nos debates sobre problemas públicos.

Com efeito, se observarmos atentamente a cena da audiência pública para discussão da anencefalia, veremos que ela foi dividida em três blocos, sendo um deles dedicado às exposições dos representantes religiosos que tiveram exatamente o mesmo tempo para a exposição de seus argumentos que os representantes da sociedade civil, dos movimentos sociais e dos órgãos representativos de classe. Essa mesma configuração foi notada em outros países como na França e na Itália, onde as disputas sobre bioética são levadas ao campo jurídico e legislativo. No caso francês analisado por Portier (2012, p. 89), o modelo radical de secularismo deixa suas marcas no debate: os agentes jurídicos deixam claro aos representantes religiosos que eles foram chamados apenas para informar o Estado de suas "palavras religiosas". Ainda assim, eles são lembrados de que serão ouvidos desde que se submetam às regras da democracia constitucional e se expressem nos termos da razão pública.

Nos casos brasileiros que tomamos como objetos de estudo, as cenas estavam organizadas sob a égide das mesmas regras (talvez de maneira não tão explícita) e os atores religiosos mostraram ser detentores das competências necessárias para participar desse tipo de confronto. Na ação referente à permissão do uso de células-tronco embrionárias em pesquisas (ADI 3510), as discussões na audiência pública foram moduladas pelo modus operandi acadêmico-científico. ${ }^{14} \mathrm{Em}$ função disso, o domínio das qualificações acadêmicas foi central para conferir

14 A CNBB teve uma participação ativa na ação sobre a possibilidade de uso de células-tronco embrionárias em pesquisas, sendo aceita como amicus curiae no processo, participando da audiência pública para a discussão do tema e constituindo advogado em defesa de sua posição. 
validade à fala dos expositores. Na verdade, todos os expositores eram cientistas ou médicos, e foi interessante observar que todos iniciavam suas falas mencionando suas qualificações profissionais, como doutorados e pós-doutorados em universidades de peso no exterior, sendo muitos deles professores em importantes universidades brasileiras (Sales, 2015). Além disso, a utilização de termos e referências científicas norteou as exposições dos dois blocos antagônicos. No caso da audiência referente ao julgamento da ação sobre a anencefalia (ADPF 54) o uso de termos e elementos das ciências também foi presente e marcante na fala dos expositores dos três blocos - cientistas, sociedade civil e religiosos - e não apenas uma competência mobilizada no bloco de "cientistas".

Quanto à encenação das justificativas chamou nossa atenção o fato de que as "palavras religiosas" ditas pelos atores não tivessem feito menção a elementos convencionalmente compreendidos como religiosos: crenças, ritos, dogmas de fé. Toda a argumentação se centrou na afirmação genérica e abstrata da vida humana como valor moral. Esse valor indisputado pelas partes permaneceu como um não dito consensual entre os contendores. Assim, foi possível perceber que a contenda não dizia respeito ao valor da vida humana, mas sim à sua definição. Os grupos contrários ao uso de células-tronco embrionárias em pesquisas científicas defenderam que a vida é humana desde o momento de sua concepção. Esse argumento pareceu ter ampla aceitação e o modo como repercutiu nos meios de divulgação demonstra que também é amplamente compartilhado pela opinião pública. ${ }^{15}$ Como parte dessa estratégia discursiva que tinha como intenção inibir o descarte de fetos, parcela significativa das justificativas produzidas pelos agentes pró-vida e seus aliados ${ }^{16}$ na controvérsia estava

15 A "defesa da vida" é repetida de diversas maneiras nas arenas onde esta controvérsia se desenvolveu. Observamos sua repetição na audiência pública sobre o tema, e também na mídia, estando presente em artigos de jornais no período em que essa controvérsia esteve ativa. Através da utilização do software de análise de discurso Atlas ti, notamos que o código "defesa da vida do inicio ao fim" foi o que mais se repetiu nesses documentos. Esse é também o argumento em torno do qual se agregam as posturas da Igreja Católica contra a eutanásia, a fertilização in vitro, o uso de células-tronco embrionárias em pesquisas, além do aborto.

16 Agentes ligados a instituições religiosas não representam a totalidade dos expositores nas audiências públicas, mas compõem um grupo de peso nas duas controvérsias. As relações e vínculos entre os expositores nas audiências públicas e entidades e instituições católicas foi notada nos dois casos em análise. Somente para nos determos em alguns exemplos dessas conexões: a primeira expositora do bloco pró-vida na audiência pública sobre as células-tronco embrionárias foi Lenise Garcia. A expositora é professora e pesquisadora da UnB, $\rightarrow$ 
relacionada ao esforço de demonstrar e produzir o estatuto de humanidade do feto, mas também do embrião ou simplesmente a célula fecundada. Tendo como ponto de partida esse duplo pressuposto moral - de que até mesmo embriões e células fecundadas deveriam ser considerados seres humanos e que toda vida humana deve ser preservada - a argumentação procurava demonstrar, sem lançar mão de argumentos teológicos, a veracidade dessa concepção. Nessa estratégia, os principais elementos da definição do humano que apareceram nos debates foram as noções de consciência e autonomia. ${ }^{17}$

Os atores do bloco antiaborto, na controvérsia sobre a anencefalia, foram insistentes em demonstrar a presença de consciência no feto anencefálico. Segundo alguns expositores, o feto anencefálico seria portador de

$\rightarrow$ na área de biologia e tem participação recorrente em eventos, congressos e palestras promovidos pela $\mathrm{CNBB}$, como o Simpósio de Bioética, realizado durante o Congresso Eucarístico Nacional de 2010, em Brasília. A participação em eventos promovidos por entidades católicas, inclusive, não se restringe à CNBB. A pesquisadora também participa de programas de rádio na Rádio Maria, em Brasília, por exemplo. Na audiência sobre as células-tronco embrionárias, Lenise se pronunciou enquanto cientista, já na segunda audiência a sua participação foi como membro da sociedade civil, representando o Movimento Nacional Brasil sem Aborto. O mesmo ocorreu com o médico e professor da UFRJ, Rodolfo Acatauassú Nunes, que se pronunciou nas duas audiências públicas. Na primeira, sobre as células-tronco embrionárias, como cientista e na segunda como porta-voz da Associação Nacional Pró-Vida e Família, ligada às pastorais da Igreja Católica, organização que integrava o bloco "religioso" na audiência sobre a anencefalia. Outro exemplo da repetição dos agentes nas duas audiências e seus vínculos com a instituição católica é a médica Elizabeth Kipman Cerqueira, também expositora nas duas audiências. A expositora foi a responsável pela elaboração do texto-base da Campanha da Fraternidade da CNBB no ano de 2008, cujo tema era "Fraternidade e defesa da vida". O texto-base da campanha traz as concepções centrais a serem trabalhadas sobre o tema da defesa da vida, possuindo formato acadêmico-científico e sendo escrito com a participação de cientistas), demonstrando mais uma vez a conexão entre os cientistas e/ou representantes de instituições da sociedade civil presentes nas duas audiências públicas e instituições católicas. O vínculo entre os agentes contrários à ação em julgamento e entidades ligadas à Igreja Católica fica evidente a partir da análise das audiências e observação da circulação e vínculos dos expositores.

17 Apesar de as duas ações transcorrerem na arena judiciária, a gramática jurídica, relacionada ao uso e interpretações da legislação, não está presente na cena das duas audiências públicas. A primeira audiência, sobre o uso de células-tronco embrionárias em pesquisas científicas, tinha caráter instrutório, os ministros queriam ser esclarecidos sobre a disputa científica sobre essa questão; assim, apenas cientistas foram aceitos como expositores e apenas argumentos científicos foram aceitos (os expositores foram impedidos de pronunciar argumentos considerados "não científicos", como argumentos teológicos ou jurídicos). Já na segunda audiência, apesar de aceitar expositores "religiosos" e da "sociedade civil", os argumentos jurídicos foram pouco presentes, sendo os termos e elementos científicos e relacionados aos direitos humanos que nortearam as exposições. 
uma "consciência primitiva". Para justificar seu argumento, um dos expositores cita a Associação Médica Americana, que apenas permite a retirada de órgãos de fetos anencéfalos em caso de sua morte por considerar que não existem meios que permitam comprovar se possuem ou não consciência. Orientação semelhante é dada pelo Conselho Federal de Medicina do Brasil. Segundo ele:

A prudência orienta esta ação da doação de órgãos devido à possibilidade da existência de uma "consciência primitiva. ${ }^{18}$

A consciência é o fundamento do ser. O tronco encefálico alto é o substrato da consciência, relacionada à capacidade de escolha do indivíduo. Todo anencéfalo possui o tronco. Ele é a porta de entrada e de saída da mente. [...] A consciência de um feto é semelhante à de um ser humano [.....$^{19}$

Nessa linha de argumentação, a "consciência primitiva" poderia existir porque a anencefalia representaria uma ausência apenas parcial do cérebro. $O$ "tronco encefálico alto" de que todo feto anencéfalo é dotado, constituiria, pois, o lócus biológico da vontade que o torna humano. É interessante observar aqui que o argumento "religioso" aceita a primazia do conceito biocientífico de humanidade que situa a vida humana no cérebro. Sua discordância está apenas na tentativa de demonstrar que o tronco poderia, na falta do cérebro, alojar as capacidades da mente.

Quanto aos argumentos relativos à autonomia dos fetos, eles também são encenados em linguagem biológica. Para demonstrar a presença da virtude de sua autonomia um dos expositores religiosos situou o debate na arena dos laboratórios de reprodução in vitro.

Para levar a discussão para o ambiente in vitro, basta constatar que o embrião cresce por ele mesmo. Após o quinto dia, se este embrião não for transferido para

18 Transcrição da exposição do representante da Associação Nacional Pró-Vida e Família, Rodolfo Acatauassú Nunes, com base no vídeo da audiência pública, disponível em: https://www.youtube. com/playlist?list=PLippyY19Z47vGsw8_FFlgBWqzkSv7njE2 (video 2/4, acesso em 16/09/2017).

19 Transcrição da exposição da representante da Associação Médica Espírita Brasileira, Marlene Rossi, com base no vídeo da audiência pública, disponível em: https://www.youtube.com/ playlist?list=PLippyY19Z47vGsw8_FFlgBWqzkSv7njE2 (vídeo 4/4, acesso em 16/09/2017). 
o útero da mãe ele morre, mas o seu desenvolvimento até este dia é autônomo (Especialista 8 - audiência sobre células-tronco embrionárias).

Logo após a fecundação, quando o embrião tem três milímetros, e já é possível ver seu coraçãozinho batendo. Será que para eu reconhecer um ser vivo eu preciso do tamanho? [...] Ele tem nele mesmo um potencial de desenvolvimento, segue um processo de autoconstrução e de autodesenvolvimento. A sua ontogênese pertence a ele mesmo. $O$ ser humano é um todo através de cada uma de suas etapas de autoconstrução. (Elisabeth Kipman Cerqueira).

Essa capacidade do embrião de se desenvolver de maneira independente seria mais uma evidência da presença de vida humana já no momento da fecundação. As palavras-chave exaustivamente repetidas pelos atores como critério para definir a vida autônoma do feto foram "autoconstrução" e "ontogênese". Assim, o desenvolvimento autônomo do embrião, sobretudo em um ambiente em que ele se encontra sozinho, apartado do corpo da mãe, seria a condição que permitiria defini-lo como um ser vivo e humano. Não é possível não reconhecer nessa representação da ontogênese o conceito clássico de "alma", que na versão do Novo Testamento poderia ser descrita como a vida de uma entidade individual consciente. É certo que o argumento não explicita o que torna essa vida humana distinta da vida in vitro dos embriões animais, não dotados de consciência e vontade. Mas o que importa nesses exemplos não é tanto a expertise no uso correto dos argumentos e a qualidade de sua fundamentação cientifica, mas, sim, sua encenação. Deixando de lado os dogmas clássicos relativos à existência da alma o "fazer religioso" se exerce nessa arena penetrando nas frestas obscuras deixadas em aberto pela lógica da ciência que só pode definir de maneira arbitrária e convencional o momento da emergência do humano.

Mas esse "secularismo estratégico" (Vaggione, 2011, p. 317) que dá forma aos argumentos dos atores de modo a engajar a opinião adquire uma configuração mais explicitamente moral quando se desenvolve no plano das tecnologias visuais. A produção de argumentos reforçados por imagens representando a autonomia do embrião humano em seu desenvolvimento, ao conferir um corpo aos argumentos científicos, moraliza o debate. Com efeito, ao longo das audiências são utilizados slides, fotos e filmes demonstrando as etapas do desenvolvimento humano, desde a fecundação até o nascimento, e mesmo posteriormente, 
com imagens de bebês recém-nascidos. Essas imagens encadeadas de maneira linear associam visualmente o embrião ao recém-nascido e, ao tornar o corpo da mãe invisível nesse processo, faz do feto o motor de seu próprio desenvolvimento. Embora se apresentem como imagens didáticas e objetivas do processo de procriação elas produzem como efeito a humanização do feto - que ganha individualidade própria na foto do bebê - e sua autonomização com relação à vontade da mãe. Esse tipo material, ao humanizar aquilo que seria objeto de um aborto, interpela as emoções da audiência transformando um potencial direito abstrato em um ato moralmente cruel. É nessa zona cinzenta em que os atores se movem entre o direito e a moral que o "fazer religioso" - enquanto a sacralização da vida emerge como experiência coletiva. Temos novamente aqui a emergência daquilo que estamos chamando de discursos trípticos, formas específicas de fazer religião indissociáveis da produção e circulação midiática nas quais as instâncias do jurídico, do religioso e do científico coexistem no próprio desempenho da comunicação religiosa. No entanto, paradoxalmente, ao atribuir vida humana aos fetos e embriões (reivindicados pelos seus contendores como matéria-prima para as experiências científicas), a comunicação religiosa ao mesmo tempo sacraliza a vida e constitui os embriões como sujeitos políticos portadores de direitos.

\section{Considerações finais}

A secularização foi apresentada, até muito recentemente como um processo de transformação das sociedades ocidentais modernas que teria levado, progressivamente, à privatização da religião. A partir da década de 1990, esse suposto começa a ser questionado. ${ }^{20} \mathrm{~A}$ literatura sobre a secularização tem colocado

20 Também no Brasil a secularização foi assumida pela sociologia da religião como um fenômeno inexorável e inerente às sociedades modernas. Mas, no final da década de 1990, inspirados nas teses da dessecularização de Peter Berger, autores como Lísias Negrão (1994) e Pierre Sanchis (1997) começam a falar sobre "o retorno do sagrado". Em reação a essa vertente, Antonio Flávio Pierucci $(1997,1998)$ faz uma releitura sistemática da obra de M. Weber, de modo a defender teoricamente a pertinência do conceito de secularização. Em 2001, a revista Religião e Sociedade dedica seu volume 21 ao debate da dessecularização, abrindo a edição com um texto de Peter Berger (2001) no qual apresenta sua perspectiva seguido de um comentário de Cecília Loreto Mariz (2001). Nesse mesmo volume, Joanildo Burity (2001) questiona os modelos normativos que associam modernização e secularização. 
consistentemente o problema das relações entre religião e Estado no centro de sua reflexão. José Casanova (1994) foi um dos autores que recolocou o debate em outro patamar teórico ao desenhar o conceito de "religiões públicas", que enfatiza o modo como as religiões ganham publicidade enquanto força de contestação moral e política. Segundo ele, as "religiões públicas" são aquelas que "assumem ou tentam assumir um papel, uma função ou um caráter público" (Casanova, 2009, p. 1). Tomando como referência a distinção analítica entre as três áreas da política moderna - o Estado, a sociedade política e a sociedade civil -, o autor distingue três tipos de "religiões públicas": as oficialmente associadas ao aparato do Estado, as que mobilizam seus recursos institucionais para a competição política por meio de partidos e/ou movimentos sociais e as que participam do debate público sobre questões públicas.

Os casos etnográficos observados neste artigo, centrados em atores que se apresentam como evangélicos e católicos na cena pública, têm como foco não tanto exemplificar esta tipologia institucional proposta por Casanova (2009), mas, sim, descrever o modo como atores específicos produzem publicamente a religião em função das mise-en-scène apresentadas nas diferentes arenas em que estão situados (Mondzain, 2015). Esse deslocamento da abordagem tem como efeito teórico mais importante desinstitucionalizar e/ou desreificar as "religiões públicas". Nosso intuito não é tanto o de caracterizar uma religião como pública, mas sim observar o que os atores fazem em cena/público em nome da religião. Como consequência desse partido teórico, a produção do fenômeno religioso não está institucionalmente definida de antemão, mas, ao contrário, a compreensão de sua emergência como experiência pública acaba por fazer parte do problema geral de sua articulação com outros sistemas funcionais.

As análises aqui apresentadas demonstraram que a religião está em relação simbiótica com os dispositivos midiáticos na produção desse tipo de experiência indexada como religiosa: a espetacularização da entronização da Arca da Aliança no templo, a replicação jornalística da biografia ao mesmo tempo materna e transgênera de Alexya emoldurada pelo altar e a humanização imagética do embrião fecundado denotam e instituem uma multiplicidade de lugares do sagrado - o templo, o corpo, o feto - e aquilo que deve ser entendido como religioso - um edifício (como os templos de Israel antigo), uma mãe de transgênera (como índice da radical inclusão cristã), um feto anancefálico (como vida humana). A partir dessa dinâmica, pode-se perceber que, paradoxalmente, 
a "função religiosa", no sentido de Peter Beyer (1998, p. 401), isto é, aquilo que as instituições religiosas reivindicam para si como forma particular de ação, quando se expressa publicamente, assume uma linguagem que só é reconhecida como "religião" quando, por meio da dramaticidade de sua performance, indexada a um referente institucionalmente religioso, faz emergir uma experiência percebida como sagrada. As dinâmicas aqui analisadas puderam demonstrar como, por meio desses dispositivos performáticos, a comunicação religiosa é capaz de projetar códigos morais a um grande leque de problemas públicos sem exigir, necessariamente, obediência a restrições dogmáticas.

Embora as mudanças nos modos de afiliação religiosa e nas formas de expressar e viver religiosamente já sejam fenômenos relativamente conhecidos e estudados (Vaggione; Faúndes, 2017), enfocar os processos de "sacralização" que designam uma experiência como religiosa - que aqui denominamos regimes de publicização - ainda nos parece merecedor de alguma atenção analítica. Descrevemos neste texto algumas características do funcionamento desse regime de mise-en-scène em três arenas distintas - a sacralização de um espaço urbano, da sexualidade/gênero, e dos embriões; nos três casos, em que religião e meios de comunicação estão em simbiose, a dramaticidade na produção de imagens foi um elemento-chave na produção da experiência religiosa como forma. Esse dispositivo, quando posto em operação ao encenar a "religião" publicamente, possibilita expandir a experiência religiosa para além da afiliação, potencializando sua capacidade de influência e/ou afetação negativa ${ }^{21}$ diante dos mais diversos públicos.

Além disso, ao fazer com que o ator religioso fale para um público geral, o dispositivo midiático produz ainda outro efeito importante que denominamos de discursos trípticos, nos quais a comunicação "propriamente religiosa" se articula com a comunicação específica de outros sistemas funcionais. Tomando como referência a teoria de Niklas Luhmann sobre a influência pública da religião,

21 Em diálogo com o conceito de Favret-Saada (2005), é importante considerar que, apesar de almejarem o convencimento, os agentes que vão a público estão cientes que esse é também um campo de batalha no qual serão reconhecidos por muitos como adversários a serem enfrentados (representantes de um outro lugar, no qual se recusam a habitar). $O$ recente processo de exposição midiática da pastora Alexya, por exemplo, gerou série de reações públicas adversas de outras lideranças religiosas, atestando pelo avesso o poder de alcance da sua fala. Isto é, Alexya também pode ser percebida como publicamente relevante quando outros reconhecem que suas palavras precisam ser combatidas. 
Peter Beyer observa que esta depende, entre outras coisas, da relação que o subsistema religioso mantém com os outros subsistemas: quando a ação religiosa é aplicada a problemas gerados em outros subsistemas, mas não resolvidos por eles, observa Beyer (1998, p. 401), a religião estabelece a sua importância para os aspectos "profanos" da vida. Os discursos trípticos da comunicação religiosa aqui descritos mostram como se dá a moralização dos problemas públicos tais como a questão das drogas referida no testemunho de fé do bispo Rogério Formigoni dirigido aos governantes na inauguração do Templo de Salomão, a questão da maternidade trans autonarrada pela pastora no altar e do aborto justificado como um desrespeito ao direito humano da vida. Os relatos de si nos testemunhos públicos e a dramaticidade das performances midiáticas tornam-se aqui instrumentos que, ao mesmo tempo, fazem emergir a experiência do sagrado lhe conferindo uma forma narrativa e a capturam como força de persuasão para o ativismo político.

Tomar a produção da religião em público em suas diversas formas e arenas como foco também nos permite revisitar o problema clássico da laicidade sem reduzi-lo à questão do controle político-jurídico da religião ou à mensuração empírica normativa dos graus de efetiva separação entre Estado e religião que ocupou farta literatura sociológica. ${ }^{22}$ Vimos que as formas de publicização aqui descritas, seja pelo testemunho de si, seja pela indexação dos problemas públicos a signos/gestos/objetos/espaços tidos como religiosos, têm potente efeito moralizador. Ao mesmo tempo, essas tecnologias de publicização do sujeito e do sagrado, que supõem uma construção moral de si que se desenvolve ao mesmo tempo no plano privado e público, coloca a experiência religiosa ao alcance de um público mais amplo, tornando-a genérica, plural e não necessariamente associada à crença, à afiliação e à obediência a postulados eclesiásticos.

Essa mutação torna mais complexa nossa compreensão das relações entre o religioso e o político subjacente à questão da laicidade. Os exemplos aqui analisados demonstram, é certo, que o grande público, pelo menos no caso da sociedade brasileira, está disponível para engajar-se na experiência religiosa publicamente dramatizada. Além disso, a sacralização midiática de experiências tem permitido que o debate sobre temas antes silenciados encontre

22 Em artigo de 2013, Giumbelli ressalta a dificuldade metodológica incontornável quando se pretende tratar a laicidade a partir de modelos normativos: como transformar princípios políticos em valores mensuráveis empiricamente (Giumbelli, 2013). 
uma fórmula narrativa ancorada nas tecnologias de testemunho, como a do amor materno para humanizar-se e elevar-se aos olhos do público como o caso da mãe transgênera Alexya, cuja família "se une em uma coisa só no momento da hóstia"; como a da "fé do ex-drogado", que se tornou pastor e oferece o relato público de sua história; ou, ao contrário, uma linguagem como a da vida humana para tornar cruel o descarte de embriões e o aborto de fetos.

É claro que a ocupação de espaços institucionais tais como cadeiras no parlamento, cargos docentes em escolas e no executivo, posições na mídia e redes de comunicação, entre outros, são pré-requisitos importantes para que uma instituição religiosa possa tornar-se publicamente influente. No entanto, como vimos nos casos aqui estudados, a modulação da experiência pública do religioso se desenvolve em diferentes arenas e pode assumir as mais diversas e imprevistas configurações. Desse modo, para enfrentar o problema da influência pública da religião, pareceu-nos necessário deslocar o foco da relação entre instituições eclesiásticas e o Estado para a observação de uma pragmática da experiência religiosa. O modo como a publicização da experiência sacraliza (moraliza) problemas privados tornando-os públicos, e engaja diferentes públicos, mostra que grande parte da eficácia da linguagem religiosa está menos na imposição de uma mensagem do que na qualidade e plasticidade de suas encenações nas diferentes arenas.

\section{Referências}

ASAD, T. Formations of the secular: Christianity, Islam, modernity. Stanford: Standford University Press, 2003.

BAPTISTA, S. Pentecostais e neopentecostais na política brasileira: um estudo sobre cultura política, Estado e atores coletivos religiosos o Brasil. São Paulo: Annablume, 2009.

BERGER, P. A dessecularização do mundo:uma visão global. Religião e Sociedade, Rio de Janeiro, v. 21, n. 1, p. 9-23, 2001.

BERTHO, H. "Sou mulher transgênera, pastora e mãe de duas crianças". UOL, 31 mar. 2017. Disponível em: <https://noticias.bol.uol.com.br/ultimas-noticias/entretenimento/2017/03/31/sou-mulher-trans-pastora-e-mae-de-duas-criancas.htm>. Acesso em: 15 ago. 2017. 
BEYER, P. A privatização e a influência pública da religião na sociedade global. In: STONE, M. F. (Org.). Cultura global: nacionalismo, globalização e modernidade. Petrópolis: Vozes, 1998. p. 395-419.

BEYER, P. Socially engaged religion in a post-Westphalian global context: remodeling the secular/religious distinction. Sociology of Religion, v. 73, n. 2, p. 102-129, June 2012.

BOORSTIN, D. J. Le triomphe de l'image: une histoire des pseudo-événements en Amérique. Montréal: Lux, 2012.

BUNCOMBE, A. Cuba hosts first transgender religious ceremony. Independent, 8 May 2017. Disponível em: <http://www.independent.co.uk/news/world/americas/ cuba-hosts-transgender-holy-communion-matanzas-communism-religious-ceremony-a7723941.html>. Acesso em: 15 ago. 2017.

BURITY, J. Novos paradigmas e o estudo da religião: uma reflexão anti-essencialista. Religião e Sociedade, Rio de Janeiro, v. 21, n. 1, p. 41-65, 2001.

BUTLER, J. Relatar a si mesmo. Belo Horizonte: Autêntica, 2015.

CAPRILIONE, L. Tudo o que você queria saber sobre a inauguração do Templo de Salomão, mas não tinha ninguém que lhe contasse. Yahoo! Notícias, 4 ago. 2014. Disponível em: <https://br.noticias.yahoo.com/blogs/laura-capriglione/tudo-o-que-voc\%C3\%AA-queria-saber-sobre-inaugura\%C3\%A7\%C3\%A3o-025715044.html>. Acesso em: 20 set. 2017.

CASANOVA, J. Public religion in the modern world. Chicago: The University of Chicago Press, 1994.

CASANOVA, J. Public religions revisited. Berlin: Henri-Böll Foundation: UNRISD, 2009.

CEFAÏ, D. Como nos mobilizamos? A contribuição de uma abordagem pragmatista para a sociologia da ação coletiva. Dilemas, v. 2; n. 4, p. 11-48, abr./jun. 2009.

CEFAÏ, D. ¿Qué es una arena pública? Algunas pautas para un acercamiento pragmático. In: CEFAÏ, D.; JOSEPH, I. La herencia del pragmatismo: conflictos de urbanidad y pruebas de civismo. Paris: L'Aube, 2012.

CEFAÏ, D.; PASQUIER, D. (Dir.). Les sens du public: publics politiques, publics médiatiques. Paris: PUF, 2003.

DECLERCQ, M. “Jesus Cristo foi o primeiro trans", diz a $1^{\mathrm{a}}$ pastora transgênera da América Latina. Vice, 29 jun. 2017. Disponível em: <https://www.vice.com/pt_br/ article/8xa943/jesus-cristo-foi-o-primeiro-trans-diz-a-la-pastora-transgenera-da-america-latina>. Acesso em: 15 ago 2017. 
FAGUNDEZ, I. 'Professora, você é homem?' A vida de uma mulher trans na sala de aula. BBC Brasil, 15 ago. 2017. Disponível em: <http://www.bbc.com/portuguese/brasil-40937289>. Acesso em: 15 ago. 2017.

FAVRET-SAADA, J. Ser afetado. Cadernos de Campo, n. 13, p. 155-161, 2005.

FÉ EM ATOS. Produção e direção: Júlia Pellizon. São Paulo: Universidade de São Paulo, 2017. 105 min.

FONTES, B. “Sempre quis ser mãe": pastora trans adota criança também trans. iGay, 30 jan. 2017. Disponível em: <http://igay.ig.com.br/2017-01-30/pastora-trans-alexya-salvador.html>. Acesso em: 1 ago. 2017.

FOUCAULT, M. História da sexualidade II: o uso dos prazeres. Rio de Janeiro: Graal, 1984.

FOUCAULT, M. História da sexualidade I: a vontade de saber. Rio de Janeiro: Graal, 1988.

GIUMBELLI, E. A presença do religioso no espaço público: modalidades no Brasil. Religião e Sociedade, Rio de Janeiro, v. 28, n. 2, p. 80-101, 2008.

GIUMBELLI, E. Crucifixos invisíveis: polêmicas recentes no Brasil sobre símbolos religiosos em recintos estatais. Anuário Antropológico 2010/I, p. 77-105, 2011.

GIUMBELLI, E. Para estudar a laicidade, procure o religioso. In: GIMÉNEZ BÉLIVEAU, V.; GIUMBELLI, E. (Coord.). Religión, cultura y política en las sociedades del siglo XXI. Buenos Aires: Biblos, 2013. p. 43-68.

HERVIEU-LÉGER, D. La religion pour mémoire. Paris: Cerf, 1993.

HERVIEU-LÉGER, D. O peregrino e o convertido. Petrópolis: Vozes, 2008.

LUCON, N. "Nasci para ser mãe", diz pastora trans Alexya Salvador que adotou menino especial e menina trans. 13 jan. 2017. Disponível em: <https://nlucon.com/2017/01/13/ nasci-para-ser-mae-diz-pastora-trans-alexya-salvador-que-adotou-menino-especial-e-menina-trans/>. Acesso em: 15 ago. 2017.

MACHADO, M. das D.; BURITY, J. (Org.). Os votos de Deus: evangélicos, política e eleições no Brasil. Recife: Fundação Joaquim Nabuco: Massangana, 2005.

MARANHÃO FILHO, E. M. (Re/des)conectando gênero e religião. Peregrinações e conversões trans* e ex-trans* em narrativas orais e do Facebook. 2014. Tese (Doutorado em História Social)-Faculdade de Filosofia, Letras e Ciências Humanas, Universidade de São Paulo, São Paulo, 2014.

MARIANO, R. Expansão e ativismo político de grupos evangélicos conservadores. Secularização e pluralismo e debate. Civitas: Revista de Ciências Sociais, v. 16, n. 4, p. 710-728, 2016. 
MARIZ, C. L. Secularização e dessecularização: comentários a um texto de Peter Berger. Religião e Sociedade, Rio de Janeiro, v. 21, n. 1, p. 25-40, 2001.

MARSH, S.; RIOS, A. Communist-ruled Cuba hosts first transgender Mass. Reuters, 7 May 2017. Disponível em: <http://www.reuters.com/article/us-cuba-lgbt-church-idUSKBN1830EZ>. Acesso em: 15 ago. 2017.

'MINHA vida é dos meus filhos': pastora trans fala sobre ser mãe. . Catraca Livre, 8 maio 2017. Disponível em: <https://catracalivre.com.br/cidadania/minha-vida-edos-meus-filhos-pastora-trans-fala-sobre-ser-mae/>. Acesso em: 1 ago. 2017.

MONDZAIN, M. J. L'image peut-elle tuer?. Montrouge: Bayard, 2015.

MONTERO, P. (Org.). Religiões e controvérsias públicas: experiências, práticas sociais e discursos. São Paulo: Terceiro Nome, 2015.

NEGRÃO, L. Intervenção. In: MOREIRA, A.; ZICMAN, R. (Org.). Misticismo e novas religiões. Petrópolis: Vozes, 1994. p. 130-135.

NOELLE-NEUMANN, E. The spiral of silence. Chicago: The University of Chicago Press, 1984.

PASTORA trans brasileira celebra missa para LGBTs em Cuba. G1, 8 maio 2017. Disponível em: <http://gl.globo.com/mundo/noticia/pastora-trans-brasileira-celebra-missa-para-lgbts-em-cuba.ghtml>. Acesso em: 15 ago. 2017.

PIERUCCI, A. F. Reencantamento e dessecularização. A propósito do autoengano em sociologia da religião. Novos Estudos CEBRAP, São Paulo, v. 49, p. 99-117, 1997.

PIERUCCI, A. F. Secularização em Max Weber: da contemporânea serventia de voltarmos a acessar aquele velho sentido. Revista Brasileira de Ciências Sociais, v. 13, n. 37, p. 43-73, 1998.

PORTIER, P. Droit, étique et religion: d'age théologique à lâge bioétique. Paris: Bruyant, 2012.

QUÉRÉ, L. Le public comme forme et comme modalité d'expérience. In: CEFAÏ, D.; PASQUIER, D. (Dir.). Les sens du public: publics politiques, publics médiatiques. Paris: PUF, 2003. p. 113-121.

RANQUETAT JR., C. A. Laicidade à brasileira: um estudo sobre as controvérsias em torno da presença de símbolos religiosos na esfera pública. 2012. Tese (Doutorado em Antropologia Social)-Instituto de Filosofia e Ciências Humanas, Universidade Federal do Rio Grande do Sul, Porto Alegre, 2012.

SANCHIS, P. A profecia desmentida. Folha de S. Paulo, São Paulo, 20 abr. 1997. Caderno Mais!, p. 5-8. 
SALES, L. A controvérsia em torno da liberação de pesquisas com células-tronco embrionárias: justificativas e moralidades. In: MONTERO, P. (Org.). Religiões e controvérsias públicas: experiências, práticas sociais e discursos. São Paulo: Terceiro Nome, 2015. p. 75-96.

SHALOM, D. Rabinos criticam uso de símbolos judaicos no Templo de Salomão. iG São Paulo, 8 set. 2014. Disponível em: <https://ultimosegundo.ig.com.br/brasil/2014-09-08/rabinos-criticam-uso-de-simbolos-judaicos-no-templo-de-salomao. html>. Acesso em: 20 set. 2017.

SILVA, A. L. A homossexualidade de um militante cristão: identidades e práticas como objetos de reflexão política e teológica. In: MONTERO, P. (Org.). Religiões e controvérsias públicas: experiências, práticas sociais e discursos. São Paulo: Terceiro Nome, 2015. p. 181-205.

SILVA, A. L. Uma igreja em marcha. Ponto Urbe, v. 19, p. 1-14, 2016.

SILVA, A. L. Ser ou não ser em nome de Deus? Notas sobre uma missão LGBTI em Uganda. Revista do Arquivo Geral da Cidade do Rio de Janeiro, v. 12, p. 201-227, 2017.

SOARES, A. C.; ZAKABI, R. "Ivanas" da vida real: transgêneros que venceram o preconceito. Veja São Paulo, 8 set. 2017. Disponível em: <https://vejasp.abril.com.br/cidades/transgeneros-sao-paulo-ivana-a-forca-do-querer/>. Acesso em: 15 ago. 2017.

TEIXEIRA, J. M. Mídia e performances de gênero na Igreja Universal: o desafio Godllywood. Religião e Sociedade, Rio de Janeiro, v. 34, n. 2, p. 232-256, 2014.

TEIXEIRA, J. M. A mulher universal: corpo, gênero e pedagogia da prosperidade. Rio de Janeiro: Mar de Ideias, 2016.

VAGGIONE, J. M. Sexualidad, religión y política en América Latina. In: CORRÊA, S.; PARKER, R. (Org.). Sexualidade e política na América Latina: histórias, interseções e paradoxos. Rio de Janeiro: ABIA, 2011. p. 286-336.

VAGGIONE, J. M.; FAÚNDES, J. M. M. (Ed.). Laicidad and religious diversity in Latin America. Cham: Springer, 2017.

VEYNE, P. Quand notre monde est devenu chrétien (312-394). Paris: Albin Michel, 2007.

Recebido: 29/09/2017 Aceito: 11/05/2018 | Received: 9/29/2017 Accepted: 5/11/2018 